\title{
Expression of cell cycle inhibitors in canine prostate with proliferative inflammatory atrophy and carcinoma
}

\author{
[Expressão de inibidores do ciclo celular na próstata canina com atrofia inflamatória \\ proliferativa e carcinoma]
}

\author{
M.B.R. Faleiro ${ }^{1}$, L.C. Cintra $^{2}$, R.S.A. Jesuino ${ }^{3}$, A.D. Damasceno ${ }^{3}$, V.M.B.D. Moura ${ }^{3}$ \\ ${ }^{1}$ Faculdade União de Goyazes - FUG - Trindade, GO \\ ${ }^{2}$ Universidade Federal de Uberlândia - UFU - Uberlândia, MG \\ ${ }^{3}$ Universidade Federal de Goiás - UFG - Goiânia, GO
}

\begin{abstract}
Gene expression of CDKN1A, CDKN1B, and TP53, and immunostaining of p21, p27 and p53 were evaluated to verify the role of these cell cycle inhibitors in canine prostates with proliferative inflammatory atrophy-PIA and prostatic carcinoma-PC. Seventy samples, 15 normal, 30PIA and 25PC. Regarding number of p27 and p53 labeled cells, difference between normal and PIA and PC was observed, as well as between PIA and PC for p53. Immunostaining intensities of p21, p27 and p53 were different when comparing normal tissues to PIA and PC. Sixteen cDNA of canine prostatic FFPE tissue were subjected to RT-PCR and RT-qPCR, four normal, three PIA, and nine PC. CDKN1A mRNA was detected in four PC by RT-PCR, and it was overexpressed when compared to normal by RT-qPCR, in one PIA and six PC. CDKN1B mRNA was detected in three PC by RT-PCR and it was overexpressed in three PC and decreased in one PC. TP53 mRNA was overexpressed in one PIA and three PC. In conclusion, when overexpressed in canine prostate with premalignant and malignant, p21 and p27 play a role controlling cell proliferation, working as a protective factor in the evolution of PIA to PC, and in the PC development, even in the presence of altered p53.
\end{abstract}

Keywords: p21, p27, p53, PIA, RT-qPCR

\section{RESUMO}

A expressão gênica de CDKN1A, CDKN1B e TP53, assim como imunomarcação de p21, p27 e p53 foram realizadas a fim de verificar o papel desses inibidores do ciclo celular na próstata canina com atrofia inflamatória proliferativa (PIA) e carcinoma prostático (PC). Foram obtidas70 amostras de próstata canina, sendo 15 de tecido normal, 30 de PIA e 25 de PC. Quanto ao número de células imunomarcadas foi observada diferença entre amostras normais, com PIA e PC para p27 e p53, assim como entre PIA e PC para p53. Para a intensidade de imunomarcação houve diferença entre os tecidos normais e com PIA e PC para p21, p27 e p53. Foram obtidas dezesseis amostras de cDNA a partir de amostras de próstatas caninas embebidas em parafina para a realização da RT-PCR e RT-qPCR, sendo quatro normais, três com PIA, e nove com o PC. O gene CDKNIA foi detectado em quatro das amostras com PC por RT$P C R$, e pela RT-qPCR este estava superexpresso em uma PIA e em seis PC quando da comparação com o tecido prostático normal. O CDKN1B foi detectado em três PC por RT-PCR e pela RT-qPCR estava superexpresso em três $P C$ e reduzido em um PC. O TP53 foi detectado em todas as próstatas caninas com PIA e PC por RT-PCR, sendo também superexpresso em uma glândula com PIA e em três com PC. Concluiu-se que p21 e p27 quando superexpressas na próstata canina com lesões pré-malignas (PIA) $e$ malignas $(P C)$ desempenham ação no controle da proliferação celular, possivelmente atuando como fator de proteção na evolução da PIA para PC, e no desenvolvimento do PC, mesmo na presença de p53 alterada. Assim, o próximo passo é avaliar essas proteínas do ciclo celular em casos de PC canino com metástase.

Palavras-chave: p21, p27, p53, PIA, RT-qPCR

Recebido em 28 de setembro de 2016

Aceito em 15 de março de 2017

E-mail: marianafavet@hotmail.com 


\section{INTRODUCTION}

The canine prostate has similarities with the human gland regarding the occurrence of benign and malignant diseases such as benign prostatic hyperplasia (BPH) and prostatic carcinoma (PC) (Leroy and Northrup 2009). Proliferative inflammatory atrophy (PIA) is also a human prostate lesion with premalignant potential and involvement in carcinogenesis of PC (Wang et al., 2009). In dogs, Rodrigues et al., (2010) have mentioned PIA in canine prostate and Toledo et al. (2010) described its histological aspects.

The proliferation of eukaryotic cells is controlled at specific points in the cell cycle, particularly at G1-S and G2-M transitions, and it is regulated by the interaction of cyclins and cyclin-dependent kinases (Cdk) and their inhibitors (CdkI`s). The major step in malignant transformation in tumors is the loss of cell cycle control. Knowing how regulators work is a key step to understand malignant transformations that occur in tumor types (Sanchez and Dynlacht, 2005).

Cyclin-dependent kinase inhibitor 1A (CDKN1A) gene encodes the p21 protein, which has been implicated in mechanisms of cell-cycle arrest from G1-S phase through different steps that allow cell DNA repair or apoptosis (Dotto, 2000). Those tasks are performed by cyclin $\mathrm{A} /$ cyclin dependent kinase $2(\mathrm{Cdk} 2)$ and cyclin D/Cdk4 complexes (Gartel and Radhakrishnan, 2005). An increased expression of CDKN1A is not necessarily linked to cell growth blocking, since the p21 protein may have a dual function, inhibiting cyclin/Cdk activity and also acting as positive modulator of cyclin/CDK complex formation (Dotto, 2000). Furthermore, studies have revealed decreased expression of p21 associated with poor prognostic in human tumors, including gastric, colorectal, prostatic, and endometrial carcinomas (Wang et al., 2010).

The $\mathrm{p} 27$ protein is encoded by cyclin-dependent kinase inhibitor 1B (CDKN1B) gene. This protein has been implicated in cell-cycle blocking mechanisms in the $\mathrm{S}$ phase. It is regulated by extracellular stimuli, like transforming growth factor beta (TGF- $\beta$ ) (Fernandez and Thomson, 2002). De Marzo et al., (1998) observed decreased expression of p27 in lesions such as BPH, PIN and PC, contributing to the high rate of mitosis in these proliferative lesions. Also, Fredersdorf et al., (1997) refer that the loss of p27 protein is a negative prognostic factor for human breast cancer.

An important protein participating in the control of the cell cycle is p53, well known as the "guardian" of the genome (May, 1999). If an error in DNA transcription occurs, p53 stops the cell cycle and promotes repair mechanisms or triggers apoptotic events leading to cell death (May, 1999). The p53 protein stimulates p21, which has regulatory functions and blocks the cell cycle's progression (May, 1999). In normal cells, wild-type p53 has a short half-life and does not accumulate in the tissue at detectable levels. Mutations or deletions of the TP53 gene may lead to altered production of p53 protein, which fails to perform its function and accumulates in the nucleus, when it is possible to detect it by immunohistochemistry (May, 1999; Fernandez and Thomson, 2002). It has been reported that the immunostaining of p53 in the canine prostate is increased in PIA and PC (Croce et al., 2011), but its role in canine prostatic tissue with proliferative lesions is not yet clear. Thus, in order to further understand the molecular mechanisms of cell cycle blocking in canine premalignant and malignant prostatic tissue, CDKN1A, CDKN1B, and TP53 mRNA expression and the immunostaining of p21, p27 and $\mathrm{p} 53$ were evaluated in canine prostates with PIA and PC.

\section{MATERIAL AND METHODS}

The samples were harvested from the necropsied animals in the pathology service of the School of Veterinary Medicine and Animal Science of the Federal University of Goiás (UFG), Goiânia, Goiás, Brazil, registered from 2008 to 2012. The research was approved by committee on publication ethics CPE/UFG number 353/2010. Three- $\mu \mathrm{m}$ sections were obtained from formalinfixed-paraffin-embedded (FFPE) tissue blocks and stained with hematoxylin and eosin (HE) for microscopic examination. Histomorphological evaluation was used to identify normal, PIA (Toledo et al., 2010) and PC (Lai et al., 2008) prostates. All prostatic samples were obtained from pure or mixed-breed adult dogs and normal prostatic tissues were harvested from dogs with no lesions in the gland. 
Prostate tissue microarray (TMA) was carried out according to criteria described by Rubin et al., (2002). From the previous defined areas in histomorphological evaluation, tissue cores with a dimension of $1.0 \mathrm{~mm}$ were taken from FFPE tissue samples and arrayed on a recipient paraffin block, in duplicate, using the tissue microarray (Beencher Instruments ${ }^{\circledR}$, Silver Spring, USA). Three- $\mu \mathrm{m}$ sections were obtained from a recipient block and distended on charged slides (Starfrost White, Sakura Adhesion microscope slide with Cut Edges, ready to use, Germany, Dako \#9545-1) for HE staining and immunohistochemistry.

Immunohistochemistry was performed in TMA slides, in duplicate, which were deparaffinized, rehydratated and washed in distilled water. Endogenous peroxidase and non-specific protein were blocked with $3 \%$ hydrogen peroxide incubation during 20 minutes, and protein block (Leica, Newcastle, UK, \#RE7102) incubation for $5 \mathrm{~min}$ at $37^{\circ} \mathrm{C}$. Antigen retrieval for p21, p27 and p53 was performed with $10 \mathrm{mM}$ pre-heated citrate buffer, $\mathrm{pH} 6.0$, for $3 \mathrm{~min}$, in a pressure cooker (Solar, Rapid Express, Tramontina, Brazil). Mouse monoclonal anti-human p21 $1^{\mathrm{WAF} 1 / \mathrm{Cip} 1}$ clone SX118 (Dako, \#M7202), monoclonal mouse anti-human $\mathrm{p} 27^{\mathrm{Kip} 1}$ clone SX53G8 (Dako, \#M7203), and monoclonal mouse p53 clone 5G176 (Santa Cruz Biotechnology, \#sc-71785) were diluted at 1:50, $1: 200$, and 1:500 respectively and incubated overnight, at $4{ }^{\circ} \mathrm{C}$ in wet chamber. A polymer kit (NovoLink Max Polymer, \#RE7260-K) was used to incubate sections with polymer enzyme, chromogen and HRP substrate for signal detection. Sections were counterstained with Mayer's hematoxylin, washed, dehydrated, cleared, cover slipped, and examined by light microscopy.

Samples from colon carcinoma were used as positive control for $\mathrm{p} 21$ and $\mathrm{p} 27$, and samples of mammary carcinoma were used for p53. For negative control, primary antibody was replaced by $\mathrm{pH}$ 7.4 PBS buffer. The intensity of reactivity of p21, p27, and p53 was scored as: $0=$ negative, $1=$ mild, $2=$ moderate, and $3=$ intense. The number of stained cells for p21, p27, and p53 was scored as: $0=$ negative, $1=1-25 \%, 2=26$ $50 \%, 3=51-75 \%$ and $4=76-100 \%$.
Before working with RNA, the microtome, the entire lab bench, the pipettors, and the sectioning equipment were cleaned with an RNase decontamination solution (Ambion ${ }^{\circledR}$ RNase Zap ${ }^{\circledR}$ Solution, Life Technologies, \#AM9780). Also, RNase-free pipette tips were used. The analysis were performed in duplicate using 20 sections with $12 \mu \mathrm{m}$ from each paraffin block, which were placed into $1.5 \mathrm{~mL}$ sterilized polypropylene microtubes. The tubes were kept at $-20^{\circ} \mathrm{C}$ until deparaffinization, digestion and RNA extraction.

The RecoverAll ${ }^{\mathrm{TM}}$ Total Nucleic Acid Isolation Kit (Life technologies, \#AM1975) was used to extract total nucleic acids (RNA) from all FFPE tissue samples that were used in the TMA. Twelve- $\mu \mathrm{m}$ sections were deparaffinized using xylene and ethanol washes followed by protein digestion with protease $\mathrm{K}$, incubation in water bath for 16 hours at $50^{\circ} \mathrm{C}$, and 15 minutes at $80^{\circ} \mathrm{C}$. Sequentially, RNA isolation and purification samples were treated with DNase mix for 30min followed by washing and finishing with the elution. The solution containing the nucleic acid (RNA) was stored at $20^{\circ} \mathrm{C}$ until proceeding the cDNA synthesis using High Capacity RNA-to-cDNA Kit (Applied Biosystems ${ }^{\circledR}$ : \#4387406).

After purification of RNA, the yield and quality were measure by NanoVue ${ }^{\text {TM }}$ Plus Spectrophotometer (GE Healthcare, UK - 289301-69 AC). The yield was estimated by UV absorbance at $260 \mathrm{~nm}$ and the quality was estimated in rates between A260/A280, using samples higher than 1.70. Likewise, the presence of RNA was confirmed by $1 \%$ agarose gel electrophoresis on PowerPac ${ }^{\mathrm{TM}}$ Basic Power Supply (Bio-Rad, \#164-5050) and the images of gels were obtained by Gel Doc ${ }^{\mathrm{TM}}$ EZ System (Bio-Rad, \#170-8270).

The High Capacity RNA-to-cDNA Kit (Applied Biosystems $^{\circledR}$ : \#4387406) was used for reverse transcription (RT) of total RNA to singlestranded cDNA using a reaction size of $20 \mu \mathrm{L}$. All the RT reactions were prepared on ice and in duplicate. In a $0.6 \mathrm{~mL}$ micro centrifuge tube was added $10 \mu \mathrm{L}$ of $2 \times \mathrm{RT}$ buffer, $1.0 \mu \mathrm{L}$ of $20 \times \mathrm{RT}$ enzyme mix, $2 \mu \mathrm{g}$ of each sample, and nucleasefree water until completing $20 \mu \mathrm{L}$. This solution was incubated at Thermal Cycler $\mathrm{T}_{100}{ }^{\mathrm{TM}}$ (Bio Rad, \#186-1096) at $37^{\circ} \mathrm{C}$ for 60 minutes, 
followed by $95^{\circ} \mathrm{C}$ for 5 minutes and storage at $20^{\circ} \mathrm{C}$ until proceeding the RT-PCR reaction.

The polymerase chain reaction (PCR) was performed in duplicate for cDNA amplification of p21 (GenBank: AJ830019.1) - Canis $l$. familiaris cyclin-dependent kinase inhibitor $1 \mathrm{~A}$ (CDKN1A) locus chromosome 12; p27 (GenBank: NM001002957.1) - C. l. familiaris cyclin-dependent kinase inhibitor 1B (CDKN1B) locus chromosome 27; p53 (GenBank: NM_001003210.1) - C. $\quad$ l. familiaris tumor protein p53 (TP53) locus chromosome 5; and $\beta$ actin, (canine housekeeping gene - GenBank: AF021873.2) - C. l. familiaris actin, gamma 1 (ACTG1) locus chromosome 9. These genes amplify fragments with $88 \mathrm{~Pb}, 124 \mathrm{~Pb}, 118 \mathrm{~Pb}$, $151 \mathrm{~Pb}$, respectively.

In each PCR microtube were inserted 100ng of cDNA; $1 \mathrm{x}$ of 10X PCR buffer $(200 \mathrm{mM}$ Tris$\mathrm{HCl} \mathrm{pH} \quad 8.4, \quad 500 \mathrm{Mm} \mathrm{KCl}) ; 2.5 \mathrm{mM}$ of Magnesium Chloride $\left(\mathrm{MgCl}_{2}-50 \mathrm{mM}\right) ; 0.2 \mathrm{mM}$ of 2'- deoxynucleoside 5'- triphosphate $(100 \mathrm{mM}$ dNTP set, PCR grade - dATP, dCTP, dGTP, dTTP - Invitrogen by life Technologies ${ }^{\text {TM }}$ \#10297-018); 0.4mMof each oligonucleotides primer [p21 Forward (Fw): ACCTCTCAGGGCCGAAAAC, reverse (Rev): TAGGGCTTCCTCTTGGAGAA; p27 Fw: CAGAGGACACACACTTGGTAGA Rev: TCTTTTGTTTTGAGGAGAGGAA; p53, Fw: CGCAAAAGAAGAAGCCACTA, Rev: TCCACTCTGGGCATCCTT; $\beta$-actin, Fw: TGGAATCATGCGGTATC Rev: GGCTGTGATTTCCTTCT] 1U of Thermusaquaticus (Taq) DNA polymerase recombinant (Invitrogen, \#11615-010) and Diethylpyrocarbonate (DEPC) treated water until completing $25 \mu \mathrm{L}$ of solution. The conditions at Thermal Cycler T100 ${ }^{\mathrm{TM}}$ (Bio Rad, \#186-1096) were: $95^{\circ} \mathrm{C}$ for 5 minutes; $95^{\circ} \mathrm{C}$ for 1 minute; $58^{\circ} \mathrm{C}$ for 30 seconds; $72^{\circ} \mathrm{C}$ for 1 minute and $72^{\circ} \mathrm{C}$ for 5 minutes; repeated 50 times. Electrophoresis in $1 \%$ Ultra Pure $^{\mathrm{TM}}$ agarose gel (Invitrogen, \#16500-100) with $0.5 \mu \mathrm{g} / \mathrm{mL}$ of Ultra Pure ${ }^{\mathrm{TM}}$ $10 \mathrm{mg} / \mathrm{ml}$ ethidium bromide $(\mathrm{EtBr}$, Invitrogen \#15585011) was performed in duplicate during 1hour of running in $80 \mathrm{~V}$ on PowerPac ${ }^{\mathrm{TM}}$ Basic Power Supply (Bio-Rad, \#164-5050) with Gene Ruler $1 \mathrm{~Kb}$ Plus DNA Ladder (Thermo scientific, \#SM1331). The amplified RT-PCR products were visualized in a Gel Doc ${ }^{\mathrm{TM}}$ EZ System (BioRad, \#170-8270). The CDKN1A, CDKN1B and TP53 primers were obtained from Klopfleisch and Gruber (2009), and the $\beta$-actin primers were obtained from Primer Quest Advanced tool (www.idtdna.com). The oligonucleotides were synthesized by Eurofins MWG Operon, and diluted with nuclease free water at concentration according to manufacturer's directions.

The cDNA samples underwent real-time quantitative reverse-transcription polymerase chain reaction (RT-qPCR) to evaluate CDKN1A, CDKN1B and TP53 gene expression. $\beta$-actin reference canine gene was used as positive control. The reactions and data analyses were performed in iQ5 real-time PCR system (Bio$\mathrm{Rad}, \# 170-9780)$. The $20 \mu \mathrm{l}$ total reactions were carried out in a 96 well polypropylene plates $\left(\mathrm{iQ}^{\mathrm{TM}}\right.$ - 96 well PCR plates, Bio-Rad, \#2239441) containing $10 \mu \mathrm{l}$ of MAXIMA ${ }^{\circledR}$ SYBRgreen Fluorescein qPCR Master mix 2x (Thermo Scientific, Fermentas, \#K0241), 500nM of each primer (forward and reverse are the same used at RT-PCR), 100ng of synthesized cDNA template, and nuclease free water. All plates were covered with optical sealing tape (Microseal ${ }^{\circledR}$ Adhesive seals Bio-Rad, \#MSB-1001).

RT-qPCR cycling conditions were 10 minutes at $95^{\circ} \mathrm{C}$, followed by 40 cycles of 30 seconds at $95^{\circ} \mathrm{C}, 1$ minute at $58^{\circ} \mathrm{C}$, and 30 seconds at $72^{\circ} \mathrm{C}$. The plates contained triplicates of each cDNA sample and $\beta$-actin gene as an internal reference to normalize the amount of total cDNA. The specificity of amplified products was confirmed by melting curve analyses. The expression level of the genes was calculated from the threshold cycle according to the $2^{-\Delta \Delta \mathrm{CT}}$ method by Livak and Schmittgen (2001) in iQ5 real-time PCR software (Bio-Rad, \#170-9780).

The Chi-square, Kruskal-Wallis, and descriptive data were used to compare the scores of percentage of positive cells and their intensity. For all data it was used SPSS (IBM Corp. Released 2010. IBM SPSS Statistics for Windows, Version 19.0. Armonk, NY: IBM Corp.) and R (R Development Core Team (2008) R Foundation for Statistical Computing, Vienna, Austria). All values were considered with $5 \%$ of significance level. 


\section{RESULTS}

From the TMA slide, $15(21.43 \%)$ samples of normal tissue, $30(42.86 \%)$ with PIA and 25 $(35.71 \%)$ with PC were obtained and scored according to the number of stained cells and the immunostaining intensity of p21, p27 and p53 (Table 1). The nuclear immunostaining of p21, p27, and p53 is shown in Figure 1.

The number of p21 stained cells in normal prostatic tissue was not different from those with PIA and PC, or between PIA and PC. The intensity of immunostaining was different between normal prostatic tissue and PIA. Also, when normal tissues were compared with PC, it was different. In contrast, there was no difference of intensity between PIA and PC. The number of p27 stained cells and immunostaining intensity was different between normal prostatic tissue and PIA, and also, between normal tissue and PC, but it did not differ when comparing PIA with PC. The number of p53 stained cells was different between normal prostatic tissue and tissues with PIA and PC, as well as between prostates with PIA and PC. Regarding the immunostaining intensity of p53, there was a difference when comparing normal prostatic tissue with PIA and PC, but there was no difference between PIA and PC $(\mathrm{P}<0.05)$ (Table 2).

Table 1. Number of cases sorted by the scores applied to the number of labeled cells and intensity of labeling for p21, p27, and p53 antibodies in canine normal prostatic tissue and with PIA and PC

\begin{tabular}{|c|c|c|c|c|c|c|c|c|c|c|}
\hline \multirow[b]{2}{*}{ Diagnoses } & \multirow[b]{2}{*}{ Antibodies } & \multicolumn{5}{|c|}{ Number of Labeled Cells Scores (\%) } & \multicolumn{4}{|c|}{ Intensity of Labeling Cells (\%) } \\
\hline & & $0(0 \%)$ & $\begin{array}{c}1 \\
1-25 \% \\
\end{array}$ & $\begin{array}{c}2 \\
26-50 \% \\
\end{array}$ & $\begin{array}{c}3 \\
51-75 \% \\
\end{array}$ & $\begin{array}{c}4 \\
76-100 \% \\
\end{array}$ & $\begin{array}{c}0 \\
\text { Negative } \\
\end{array}$ & $\begin{array}{c}1 \\
\text { mild }\end{array}$ & $\begin{array}{c}2 \\
\text { moderate }\end{array}$ & $\begin{array}{c}3 \\
\text { intense } \\
\end{array}$ \\
\hline \multirow{3}{*}{$\begin{array}{l}\text { Normal } \\
\mathrm{N}=15\end{array}$} & $\mathrm{p} 21$ & $\begin{array}{c}46.6 \% \\
\text { (7) }\end{array}$ & $0 \%$ & $\begin{array}{c}26.67 \% \\
\text { (4) }\end{array}$ & $\begin{array}{l}20 \% \\
(3)\end{array}$ & $\begin{array}{c}6.67 \% \\
\text { (1) }\end{array}$ & $\begin{array}{c}46.67 \% \\
\text { (7) }\end{array}$ & $\begin{array}{c}53.33 \% \\
(8)\end{array}$ & $0 \%$ & $0 \%$ \\
\hline & $\mathrm{p} 27$ & $\begin{array}{c}46.67 \% \\
\text { (7) }\end{array}$ & $\begin{array}{c}6.67 \% \\
(1)\end{array}$ & $\begin{array}{c}33.33 \% \\
(5)\end{array}$ & $\begin{array}{c}13.33 \% \\
\text { (2) }\end{array}$ & $0 \%$ & $\begin{array}{c}46.67 \% \\
(7)\end{array}$ & $\begin{array}{c}53.33 \% \\
(8)\end{array}$ & $0 \%$ & $0 \%$ \\
\hline & $\mathrm{p} 53$ & $\begin{array}{c}73.33 \% \\
(11)\end{array}$ & $\begin{array}{l}20 \% \\
(3)\end{array}$ & $\begin{array}{c}6.67 \% \\
(1)\end{array}$ & $0 \%$ & $0 \%$ & $\begin{array}{c}73.33 \% \\
(11)\end{array}$ & $\begin{array}{l}26.67 \% \\
(4)\end{array}$ & $0 \%$ & $0 \%$ \\
\hline \multirow{3}{*}{$\begin{array}{c}\text { PIA } \\
\mathrm{N}=30\end{array}$} & $\mathrm{p} 21$ & $\begin{array}{c}13.33 \% \\
(4)\end{array}$ & $\begin{array}{c}6.67 \% \\
(2)\end{array}$ & $\begin{array}{c}13.33 \% \\
(4)\end{array}$ & $\begin{array}{l}40 \% \\
(12)\end{array}$ & $\begin{array}{c}26.67 \% \\
(8)\end{array}$ & $\begin{array}{c}13.33 \% \\
\text { (4) }\end{array}$ & $\begin{array}{c}56.67 \% \\
(17)\end{array}$ & $\begin{array}{c}23.33 \% \\
(7)\end{array}$ & $\begin{array}{c}6.67 \% \\
(2)\end{array}$ \\
\hline & $\mathrm{p} 27$ & $\begin{array}{c}13.33 \% \\
(4)\end{array}$ & $\begin{array}{c}6.67 \% \\
(2)\end{array}$ & $\begin{array}{c}23.33 \% \\
\text { (7) }\end{array}$ & $\begin{array}{c}43.33 \% \\
(13)\end{array}$ & $\begin{array}{c}13.33 \% \\
(4)\end{array}$ & $\begin{array}{c}13.33 \% \\
(4)\end{array}$ & $\begin{array}{c}36.67 \% \\
(11)\end{array}$ & $\begin{array}{l}40 \% \\
(12)\end{array}$ & $\begin{array}{c}6.67 \% \\
\text { (2) }\end{array}$ \\
\hline & $\mathrm{p} 53$ & $\begin{array}{c}6.67 \% \\
(2)\end{array}$ & $0 \%$ & $\begin{array}{l}70 \% \\
(21)\end{array}$ & $\begin{array}{l}10 \% \\
(3)\end{array}$ & $\begin{array}{c}13.33 \% \\
(4)\end{array}$ & $\begin{array}{c}6.67 \% \\
(2)\end{array}$ & $\begin{array}{c}83.33 \% \\
(25)\end{array}$ & $10 \%(3)$ & $0 \%$ \\
\hline \multirow{3}{*}{$\begin{array}{c}\text { Carcinoma } \\
\mathrm{N}=25\end{array}$} & $\mathrm{p} 21$ & $\begin{array}{l}24 \% \\
(6)\end{array}$ & $\begin{array}{l}8 \% \\
(2)\end{array}$ & $\begin{array}{l}8 \% \\
(2)\end{array}$ & $\begin{array}{l}12 \% \\
(3)\end{array}$ & $\begin{array}{l}48 \% \\
(12)\end{array}$ & $\begin{array}{c}24 \% \\
(6)\end{array}$ & $\begin{array}{l}24 \% \\
(6)\end{array}$ & $\begin{array}{l}12 \% \\
(3)\end{array}$ & $\begin{array}{l}40 \% \\
(10)\end{array}$ \\
\hline & $\mathrm{p} 27$ & $\begin{array}{l}16 \% \\
(4)\end{array}$ & $0 \%$ & $\begin{array}{l}24 \% \\
(6)\end{array}$ & $\begin{array}{l}20 \% \\
(5)\end{array}$ & $\begin{array}{l}40 \% \\
(10)\end{array}$ & $\begin{array}{l}16 \% \\
(4)\end{array}$ & $\begin{array}{l}24 \% \\
(6)\end{array}$ & $\begin{array}{l}20 \% \\
(5)\end{array}$ & $\begin{array}{l}40 \% \\
(10)\end{array}$ \\
\hline & $\mathrm{p} 53$ & $\begin{array}{l}4 \% \\
(1)\end{array}$ & $\begin{array}{l}4 \% \\
(1)\end{array}$ & $\begin{array}{l}24 \% \\
(6)\end{array}$ & $\begin{array}{l}8 \% \\
(2)\end{array}$ & $\begin{array}{l}60 \% \\
(15)\end{array}$ & $\begin{array}{l}4 \% \\
(1)\end{array}$ & $\begin{array}{l}60 \% \\
(15)\end{array}$ & $\begin{array}{l}28 \% \\
(7)\end{array}$ & $\begin{array}{l}8 \% \\
(2)\end{array}$ \\
\hline
\end{tabular}

Sixteen cDNA samples of canine prostatic tissue were obtained to perform RT-PCR, in which there were $4(25 \%)$ samples of normal tissue, 3 $(18.75 \%)$ with PIA, and $9(56.25 \%)$ with PC. CDKN1A mRNA was detected in four of the nine PC samples (4/9 - PC6, PC7, PC8, PC9) and CDKN1B mRNA in three of the nine PC samples (3/9 - PC7, PC8, PC9). TP53 gene expression was detected in all PIA and PC samples, but not in normal prostatic tissue (Figure 2).

The expression of $C D K N 1 A, C D K N 1 B$ and TP53 in canine normal prostates, and prostates with PIA and PC was determined by RT-qPCR and fold change (FC) normalized with $\beta$-actin expression from the same dog and with a normal gland with $\mathrm{T}$ melt $84.8^{\circ} \mathrm{C}$. The $C D K N 1 A$ was overexpressed in seven of sixteen tissues investigated (PIA1, PC1, PC3, PC4, PC7, PC8 and $\mathrm{PC} 9$ ) with $\mathrm{FC}>1.6$ when compared to normal glands (N1 to N4) and $\mathrm{T}$ melt $76.9^{\circ} \mathrm{C}$. The $C D K N 1 B$ was overexpressed in three of nine PC tumors (PC7, PC8, PC9) with FC>1.6, and it was under expressed in one of the nine $\mathrm{PC}$ ( $\mathrm{PC} 2)$ samples based on $\mathrm{FC}<0.4$ and $\mathrm{T}$ melt $80.5^{\circ} \mathrm{C}$. Regarding TP53, overexpression was present in five of sixteen prostatic samples (PIA1, PC4, PC6, PC8, PC9) with FC>1.6, and decreased expression was observed in two of sixteen prostatic tissues (PIA2, PC2) based on $\mathrm{FC}<0.4$ and $\mathrm{T}$ melt $78.8^{\circ} \mathrm{C}$ (Figure 3 ). 
Expression of cell...

Table 2. Comparison between p21, p27, and p53 immunostaining regarding the number of stained cells and the intensity of staining in canine normal prostatic tissue, PIA and PC

\begin{tabular}{cccccccc}
\multirow{2}{*}{ Diagnoses } & \multirow{2}{*}{$\mathrm{N}$} & \multicolumn{2}{c}{ Rank of Number of Stained Cells } & \multicolumn{3}{c}{ Rank of Staining Intensity } \\
\cline { 3 - 7 } & & $\mathrm{p} 21$ & $\mathrm{p} 27$ & $\mathrm{p} 53$ & $\mathrm{p} 21$ & $\mathrm{p} 27$ & $\mathrm{p} 53$ \\
\hline Normal & 15 & $46.3 \mathrm{a}$ & $34.4 \mathrm{a}$ & $16.9 \mathrm{a}$ & $33.9 \mathrm{a}$ & $31.6 \mathrm{a}$ & $23.0 \mathrm{a}$ \\
PIA & 30 & $57.8 \mathrm{a}$ & $60.1 \mathrm{~b}$ & $54.6 \mathrm{~b}$ & $55.8 \mathrm{~b}$ & $60.4 \mathrm{~b}$ & $55.7 \mathrm{~b}$ \\
Carcinoma & 25 & $59.8 \mathrm{a}$ & $67.4 \mathrm{~b}$ & $75.2 \mathrm{c}$ & $64.3 \mathrm{~b}$ & $68.6 \mathrm{~b}$ & $68.2 \mathrm{~b}$
\end{tabular}

Similar letters in the same column are not different by the non-parametric multiple comparison test for paired contrasts the relative effects with Tukey correction. $(\mathrm{P}<0.05)$.

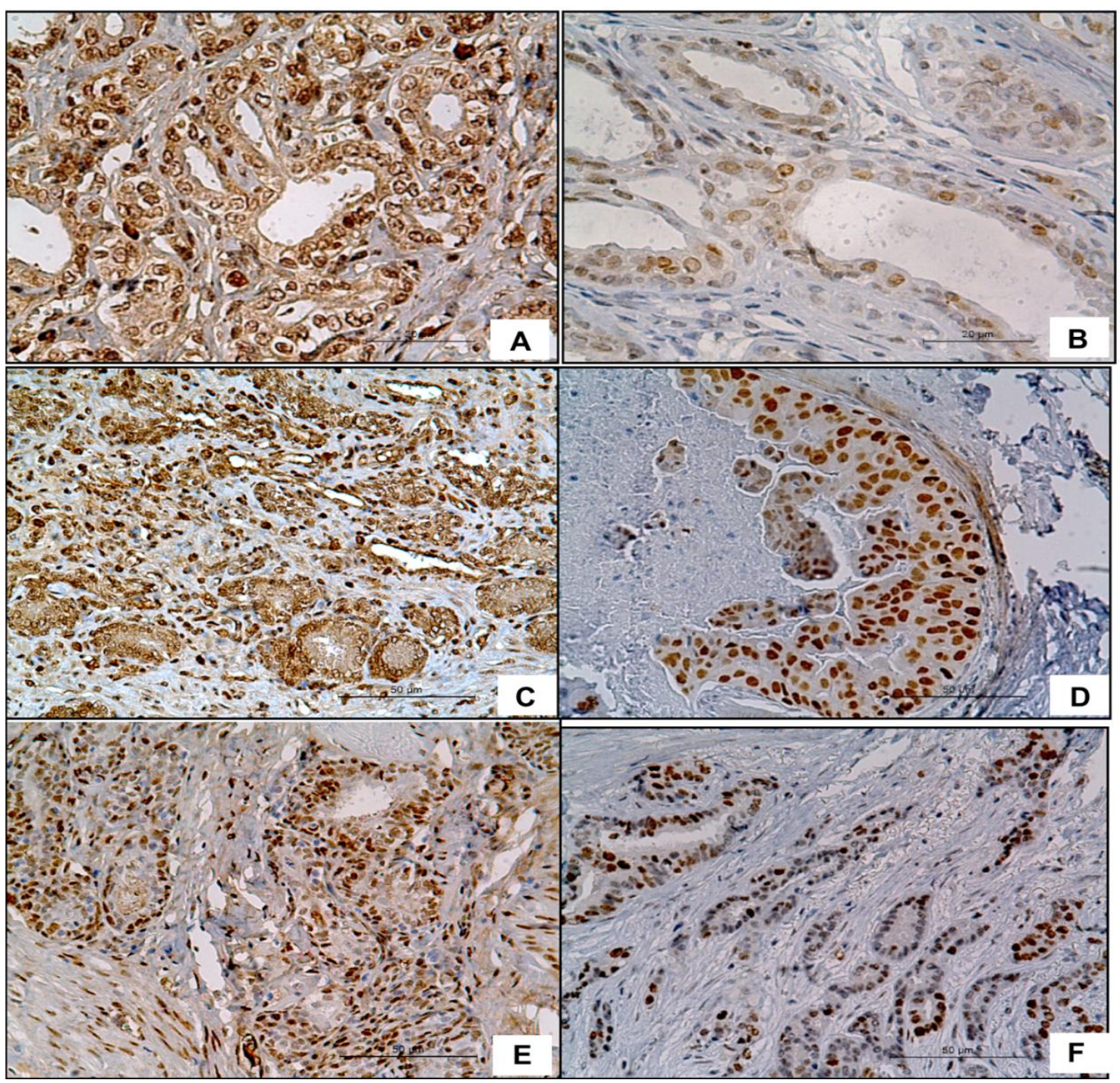

Figure 1. Immunohistochemistry photomicrography on nuclear immunostaining. A) Canine PC tissue with score three for labeling intensity and four for the number of labeled cells for p21. 400x. B) Human colon carcinoma; p21 positive control with score two for labeling intensity and four for the number of labeled cells. 400x. C) Canine PIA tissue with score three for labeling intensity and four for the number of labeled cells for p27. 200x. D) Human colon carcinoma; p27 positive control with score three for labeling intensity and four for the number of labeled cells. 200x. E) Canine PC tissue with score three for labeling intensity and four for the number of labeled cells for p53. 200x. F) Human mammary carcinoma; p53 positive control with score three for labeling intensity and three for the number of labeled cells. 200x. IHC, DAB with hematoxylin counterstain. 


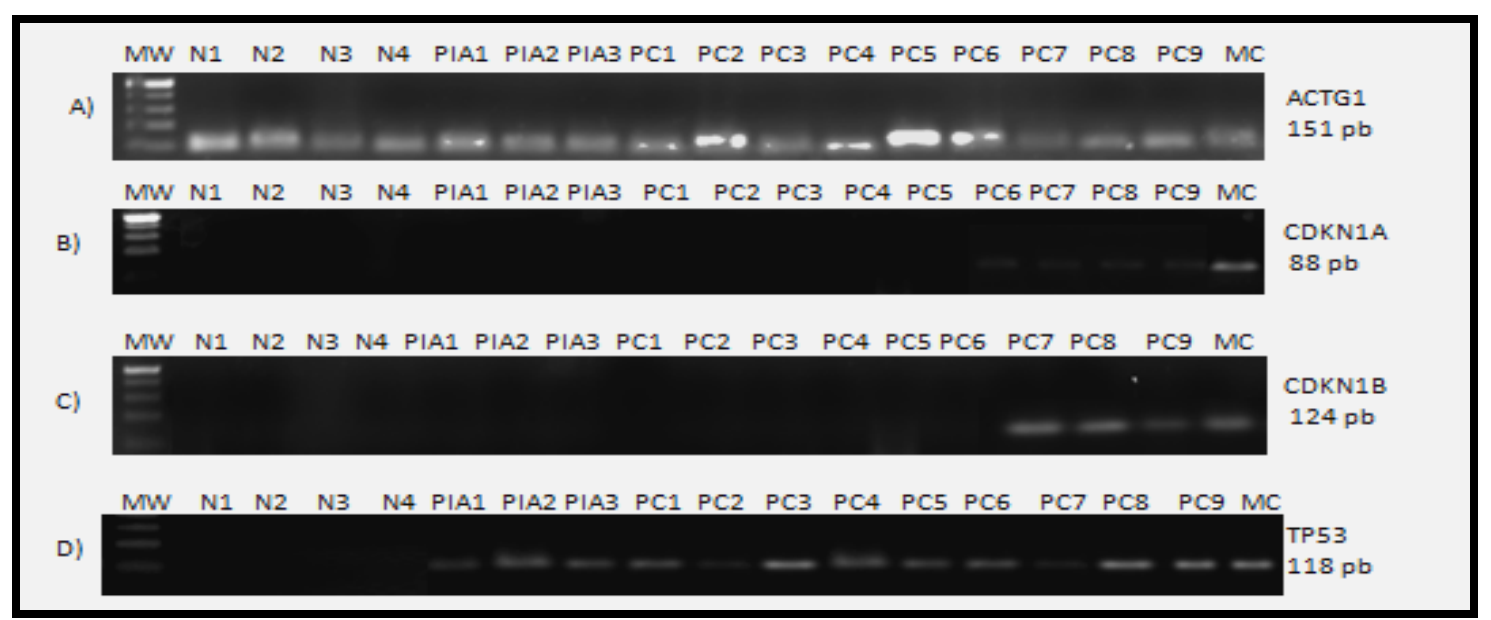

Figure 2. Images from agarose gels showing the amplification products of ACTG1 ( $\beta$-actin), CDKN1A, CDKN1B and TP53 genes from canine prostatic tissue. (A) RT-PCR for $\beta$-actin expression (positive control). (B) RT-PCR for CDKN1A. Prostatic samples PC6, PC7, PC8, PC9 and MC amplified. (C) RTPCR for CDKN1B. Prostatic samples PC7, PC8, PC9 and MC amplified. (D) RT-PCR for TP53. Prostatic samples PIA1, PIA2, PIA3, PC1, PC2, PC3, PC4, PC5, PC6, PC7, PC8, PC9 and MC amplified. MW = Molecular weight (Gene Ruler 1Kb Plus DNA Ladder - Thermo scientific, CA, USA, \#SM1331); MC= canine mammary carcinoma (CDKN1A, CDKN1B and TP53 positive control); $\mathrm{N}=$ Normal tissue; PIA= Canine proliferative inflammatory atrophy; $\mathrm{PC}=$ Canine prostatic carcinoma.

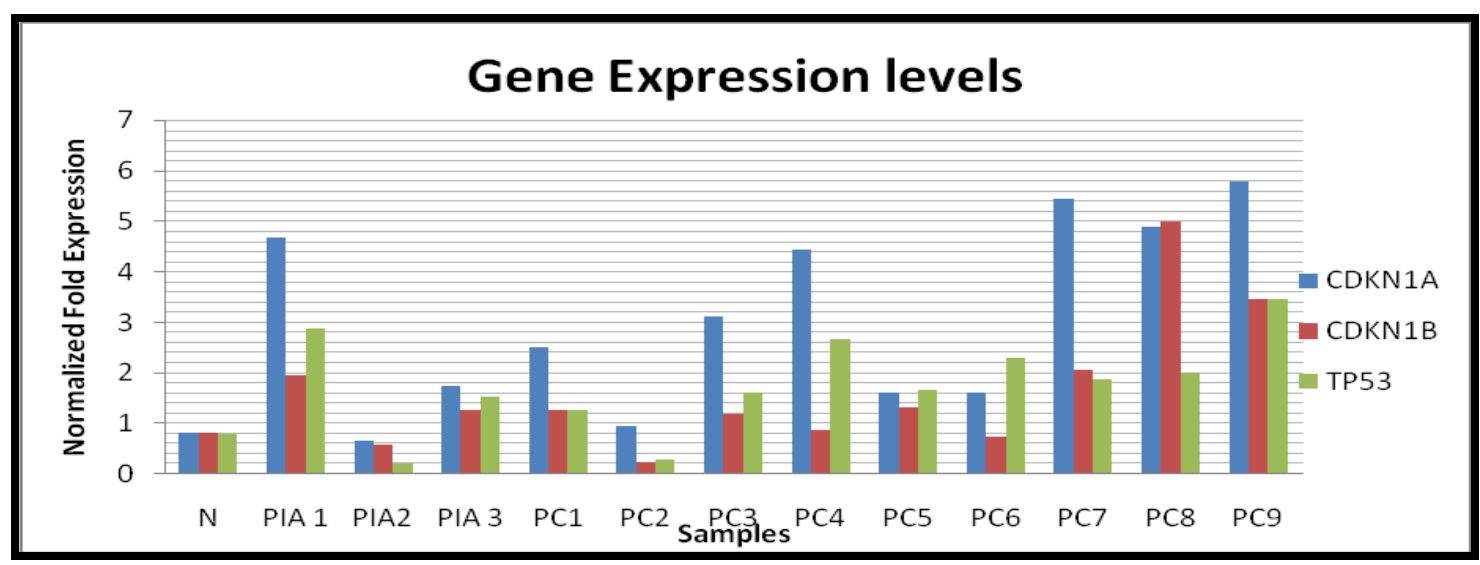

Figure 3. Fold expression levels of CDKN1A, CDKN1B and TP53 in canine normal prostatic tissue, PIA and PC normalized by $\beta$-actin. Values $>1.6$ were considered overexpression and values $<0.4$ were considered decrease of gene expression.

A commercial kit for extraction enabled the obtainment of DNA and RNA from FFPE canine prostate tissue with good enough quality and quantity to perform the RT-PCR test successfully. Isolating nucleic acids from tissues in sufficient amount, purity and integrity is an essential step in the practice of molecular biology. The quantity, purity and integrity of the extracted nucleic acids depend on the time of pre-fixation, and the time and temperature used in FFPE process (Ribeiro-Silva and Garcia,
2008). Thus, extracting RNA with good quality and quantity is a feasible and valuable tool in diagnostic routine and retrospective studies (Ribeiro-Silva and Garcia, 2008).

Comparison of results referring to $\mathrm{p} 21, \mathrm{p} 27$ and p53 immunostaining by IHC and CDKN1A, CDKN1B and TP53 detection by RT-PCR and expression by RT-qPCR are described in Table 3. 
Table 3. Comparison between p21, p27, and p53 immunostaining regarding the number of stained cells and intensity of staining in canine normal prostatic tissue, PIA and PC

\begin{tabular}{cccccccccc}
\hline \multirow{2}{*}{ Samples } & \multicolumn{3}{c}{ IHC } & \multicolumn{3}{c}{ RT-PCR } & \multicolumn{3}{c}{ RT-qPCR } \\
\cline { 2 - 10 } & $\mathrm{p} 21$ & $\mathrm{p} 27$ & $\mathrm{p} 53$ & CDKN1A & CDKN1B & TP53 & CDKN1A & CDKN1B & TP53 \\
\hline N1 & 0 & 0 & 0 & - & - & - & $\mathrm{R}$ & $\mathrm{R}$ & $\mathrm{R}$ \\
N2 & 0 & 0 & 0 & - & - & - & $\mathrm{R}$ & $\mathrm{R}$ & $\mathrm{R}$ \\
N3 & $2 / 1$ & $2 / 1$ & 0 & - & - & - & $\mathrm{R}$ & $\mathrm{R}$ & $\mathrm{R}$ \\
N4 & 0 & 0 & $1 / 1$ & - & - & - & $\mathrm{R}$ & $\mathrm{R}$ & $\mathrm{R}$ \\
PIA1 & $4 / 3$ & $2 / 1$ & $4 / 3$ & - & - & + & $\mathrm{O}$ & $\mathrm{R}$ & $\mathrm{O}$ \\
PIA2 & $2 / 2$ & $2 / 1$ & $1 / 1$ & - & - & + & $\mathrm{R}$ & $\mathrm{R}$ & $\mathrm{D}$ \\
PIA3 & 0 & $2 / 1$ & $2 / 2$ & - & - & + & $\mathrm{R}$ & $\mathrm{R}$ & $\mathrm{R}$ \\
PC1 & $4 / 3$ & $4 / 3$ & $2 / 2$ & - & - & + & $\mathrm{O}$ & $\mathrm{R}$ & $\mathrm{R}$ \\
PC2 & 0 & 0 & 0 & - & - & + & $\mathrm{R}$ & $\mathrm{D}$ & $\mathrm{D}$ \\
PC3 & $4 / 3$ & $4 / 3$ & $2 / 2$ & - & - & + & $\mathrm{O}$ & $\mathrm{R}$ & $\mathrm{R}$ \\
PC4 & $4 / 3$ & $4 / 3$ & $4 / 3$ & - & - & + & $\mathrm{O}$ & $\mathrm{R}$ & $\mathrm{O}$ \\
PC5 & $2 / 1$ & $3 / 2$ & $2 / 3$ & - & - & + & $\mathrm{R}$ & $\mathrm{R}$ & $\mathrm{R}$ \\
PC6 & $3 / 2$ & $3 / 2$ & $4 / 3$ & + & - & + & $\mathrm{R}$ & $\mathrm{R}$ & $\mathrm{O}$ \\
PC7 & $4 / 3$ & $4 / 3$ & $3 / 2$ & + & + & + & $\mathrm{O}$ & $\mathrm{O}$ & $\mathrm{R}$ \\
PC8 & $4 / 3$ & $4 / 3$ & $3 / 2$ & + & + & + & $\mathrm{O}$ & $\mathrm{O}$ & $\mathrm{O}$ \\
PC9 & $4 / 3$ & $4 / 3$ & $4 / 3$ & + & + & + & $\mathrm{O}$ & $\mathrm{O}$ & $\mathrm{O}$ \\
MC & $4 / 3$ & $4 / 3$ & $4 / 2$ & + & + & + & $\mathrm{R}$ & $\mathrm{R}$ & $\mathrm{R}$ \\
\hline
\end{tabular}

$\mathrm{MC}=$ canine mammary carcinoma; $\mathrm{N}=$ canine normal prostatic tissue; $\mathrm{PIA}=$ canine proliferative inflammatory atrophy; $\mathrm{PC}=$ canine prostatic carcinoma; $\mathrm{N} / \mathrm{N}=$ score of number of stained cells/ score of staining intensity; $\mathrm{R}=$ regular expression; $\mathrm{D}=$ decreased expression; and $\mathrm{O}=$ overexpression.

\section{DISCUSSION}

Immunostaining of the protein $\mathrm{p} 21$ was intense in $40 \%$ of PC and $6.7 \%$ of PIA. In normal tissue, the immunolabeling was weak in $53.3 \%$ and absent in $46.7 \%$. Protein p21 plays an important function in the cell cycle and its increased expression may mean a crucial step in cell growth blocking, inducing senescence or apoptosis, a mechanism which seems to protect against malignant transformation (Lin et al., 2007; Majid et al., 2008; Inoue et al., 2013). Thus, loss of p21 expression has been associated with shorter survival in human with PC (Wang et al., 2010). Also, according to Matsushima et al., (1998), immunostaining of p21 was more likely to be expressed in well-differentiated areas.

Likewise, there was a difference between normal prostatic tissue and tissues with PIA and PC regarding the intensity of immunostaining for p21, and there was no difference between groups considering the number of stained cells. In this context, our results suggest that p21 could work as a protective factor in canine PC progression, since in human PC the overexpression of p21 is associated with good prognosis (Wang et al., 2010). Furthermore, considering the possibility that canine PC shows high aggressiveness when present (Leroy and Northrup, 2009), this tumor is not as common in the canine prostate as it is in the human prostate. It seems that canine PC has longer time development, which could be linked to the action of inhibitors such as p21 and p27 during the canine $\mathrm{PC}$ progression. This hypothesis was mentioned before in canine prostate, but it was referring to proteins from other regulatory pathways like GSTP1 (Croce $e t$ al., 2011). Also, it seems that immunostaining intensity of p21 in canine prostate tumors should be considered.

Klopfleisch and Gruber (2009) reported p21 overexpression in canine malignant mammary tumors, but concluded that its increase alone did not avoid metastasis and an explanation for that would be a loss of p21's function by missense mutations. On the other hand, Wang et al. (2010) added that the overexpression of p21 in human prostate may be associated with poor prognostic due to CDKN1A instability, or it may be caused by the indirect alteration of its function by TGF$\beta$ (Dotto 2000), PTEN deficiency (Lin et al., 2007), and TP53 mutation (Stangelberger et al., 2012). Since p21 may play a double function, acting as a tumoral suppressor or oncogene (Dotto, 2000) depending on the tumor type, and considering our results, it seems that p21 could be involved in the control of cell proliferation in canine prostate with proliferative lesions as observed in human breast cancer (Knappskog et al., 2007). 
Taken together, the results from this research concerning p21 and p27 inhibitors indicate that a positive relation of their overexpression in canine proliferative prostatic tissue could work by controlling cell proliferation. Similar to p21, p27 protein is an important cell proliferation inhibitor (Wang et al., 2012), once increased levels of p27 result in cell cycle blocking in the $\mathrm{S}$ phase (Fernandez and Thomson, 2002; Klopfleisch et al., 2010; Wang et al., 2012). The p27 expression may be lost or decreased in human PC (Halvorsen et al., 2003), a feature associated with tumor cell undifferentiation, proliferation and poor prognostic (Wang et al., 2012). In contrast to p21, the overexpression of p27 is mostly related to better prognosis, acting as a tumoral suppressor (Yong et al., 2014). However, it seems important to evaluate these cell cycle inhibitors together, since there are studies showing an association of malignant progression and the presence of a negative relation between the expression of p21 (overexpressed) and p27 (underexpressed) in canine mammary tumor (Klopfleisch and Gruber, 2009), as well as a malignant progression and a positive relation between the expression of $\mathrm{p} 21$ (underexpressed) and p27 (underexpressed) in human tumors (Abukhdeir and Park, 2008). In contrast, in canine prostate with premalignant and malignant lesions the positive relation in the overexpression of p21 and p27 would be related to a good prognosis.

Another important protein in cell cycle control is the product of TP53 gene, the p53 protein (May 1999). In this study, the number of stained cells for p53 was significantly higher in canine prostates with PC than with PIA. TP53 mRNA was detected by RT-PCR in all prostates with PIA and PC, but TP53 overexpression detected by RT-qPCR was present in a higher number of prostates with PC than with PIA. According to Tsujimoto et al., (2002), and Stangelberger et al., (2012), in human prostates with PIA, prostatic intraepithelial neoplasia (PIN), and PC, the increased expression of p53 has been associated with high proliferative index and more aggressive phenotype. Since the accumulations of p53 in the presence of TP53 gene mutation are usual, our results indicate that alterations related to the p53 protein may start in canine prostates with PIA and later it accentuates in canine glands with PC, emphasizing its malignant potential as described before in dogs (Croce et al., 2011) and humans (Tsujimoto et al., 2002). This hypothesis is also supported by the fact that inflammatory microenvironment in PIA promotes changes in the TP53 gene, as mentioned by Wang et al., (2009) and Tsujimoto et al., (2002). Furthermore, according to Wang et al., (2009), p53 accumulations occur in the presence of a TP53 gene mutation, especially in tissues with chronic inflammation, such as cholangiohepatitis, gastritis and colitis. Tsujimoto et al., (2002) also detected TP53 overexpression in human post-atrophic hyperplasia.

Taken together, our results have showed that it is important to evaluate different cell pathways in order to better understand the carcinogenesis and tumoral development steps in different types of tissue and species, since one lesion in the organism may evolute through different mechanisms with similar biological results (Croce et al., 2011). Based on that, it seems that in canine premalignant and malignant prostatic tissue the overexpression of p21 and p27 plays a role controlling cell proliferation and lesion progression even with the evidence of alterations involving $\mathrm{p} 53$.

\section{CONCLUSIONS}

When overexpressed in canine premalignant (PIA) and malignant prostatic (PC) tissue, p21 and p27 play a role controlling cell proliferation, most likely working as a protective factor in the evolution of PIA to PC, and in the PC development, even in the presence of altered p53. Thus, the next step would be verifying these cell cycle proteins in canine prostate with PC and metastasis.

\section{REFERENCES}

ABUKHDEIR, A.M.; PARK, B.H. p21 and p27: roles in carcinogenesis and drug resistance. Expert Rev. Mol. Med., v.10, p. e19, 2008.

CROCE, G.B.; RODRIGUES, M.M.P.; FALEIRO, M.B.R. et al. Óxido nítrico, GSTP-1 e p53: qual o papel desses biomarcadores nas lesões prostáticas do cão? Arq. Bras. Med. Vet. Zootec., p.1368-1376, 2011. 
DE MARZO, A.M.; MEEKER, A.K.; EPSTEIN, J.I. et al. Prostate stem cell compartments: expression of the cell cycle inhibitor p27kip 1 in normal, hyperplastic, and neoplastic cells. Am. J. Pathol., v.153, p.911-919, 1998.

DOTTO, G.P. p21WAF1/Cip1: more than a break to the cell cycle? [minireview]. Biochim. Biophys. Acta, v.1471, p.M43-M56, 2000.

FERNANDEZ, P.L.; THOMSON, T.M. Alterations of genes and their expression in prostate carcinoma. In: HAYAT, M.A. Handbook of immunohistochemistry and in situ hybridization of human carcinomas. Molecular pathology, colorectal carcinoma and prostate carcinoma. New York: Elsevier Academic Press, 2002. v.2, p.307-320.

FREDERSDORF, S.; BURNS, J.; MILNE, A.M. et al. High level expression of p27(kip1) and cyclin D1 in some human breast cancer cells: inverse correlation between the expression of p27(kip1) and degree of malignancy in human breast and colorectal cancers. Proc. Natl. Acad. Sci., v.94, p.6380-6385, 1997.

GARTEL, A.L.; RADHAKRISHNAN, S.K. Lost in transcription: p21 repression, mechanisms, and consequences. Cancer Res., v.65, p.39803985, 2005.

HALVORSEN, O.J.; HAUKAAS, S.A.; AKSLEN, L.A. Combined loss of PTEN and p27 expression is associated with tumor cell proliferation by $\mathrm{Ki}-67$ and increased risk of recurrent disease in localized prostate cancer. Clin. Cancer Res., v.9, p.1474-1479, 2003.

INOUE, S.; HAO, Z.; ELIA, A.J. et al. Mule/Huwe1/Arf-BP1 suppresses Ras-driven tumorigenesis by preventing c-Myc/Miz1mediated down-regulation of $\mathrm{p} 21$ and $\mathrm{p} 15$. Genes Dev., v.27, p.1101-1114, 2013.

KLOPFLEISCH, R.; GRUBER, A.D. Differential expression of cell cycle regulators p21, p27 and p53 in metastasizing canine mammary adenocarcinomas versus normal mammary glands. Res. Vet. Sci., v.87, p.91-96, 2009.

KLOPFLEISCH, R.; SCHUTZE, M.; GRUBER, A.D. Loss of p27 expression in canine mammary tumors and their metastases. Res. Vet. Sci., v.88, p.300-303, 2010.
KNAPPSKOG, S.; CHRISANTHAR, R.; STAALESEN, V. et al. Mutations and polymorphisms of the $\mathrm{p} 21 \mathrm{~B}$ transcript in breast cancer. Int. J. Cancer, v.121, p.908-910, 2007.

LAI, C.L.; VAN DEN HAM, R.; VAN LEENDERS, G. et al. Histopathological and immunohistochemical characterization of canine prostate cancer. Prostate, v.68, p.477-488, 2008.

LEROY, B.E.; NORTHRUP, N. Prostate cancer in dogs: comparative and clinical aspects. Vet. J., v.180, p.149-162, 2009.

LIN, P.Y.; FOSMIRE, S.P.; PARK, S.H. et al. Attenuation of PTEN increases p21 stability and cytosolic localization in kidney cancer cells: a potential mechanism of apoptosis resistance. Mol. Cancer, v.6, p.1, 2007.

LIVAK, K.J.; SCHMITTGEN, T.D. Analysis of relative gene expression data using real-time quantitative PCR and the $2^{-\Delta \Delta C T}$ method. Methods, v.25, p.402-408, 2001.

MAJID, S.; KIKUNO, N.; NELLES, J. et al. Genistein induces the $\mathrm{p} 21^{\mathrm{WAF} 1 / \mathrm{CIP} 1}$ and $\mathrm{p} 16^{\mathrm{INK} 4 \mathrm{a}}$ tumor suppressor genes in prostate cancer cells by epigenetic mechanisms involving active chromatin modification. Cancer Res., v.68, p.2736-2744, 2008.

MATSUSHIMA, H.; SASAKI, T.; GOTO, T. et al. Immunohistochemical study of $\mathrm{p} 21^{\mathrm{WAF} 1}$ and p53 protein in prostate cancer and their prognostic significance. Hum. Pathol., v.29, p.778-783, 1998.

MAY, P. Twenty years of p53 research: structural and functional aspects of the p53 protein. Oncogene, v.18, p.7621-7636, 1999.

RIBEIRO-SILVA, A.S.; GARCIA, S.B. Comparative study of three different procedures for RNA extraction from formalin-fixed paraffinembedded samples. J. Bras. Patol. Med. Lab., v.44, p.123-130, 2008.

RODRIGUES, M.M.P.; DI SANTIS, G.W.; DE MOURA, V.M.B.D. et al. COX-2 and TGF- $\beta$ expression in proliferative disorder canine prostate. Braz. J. Vet. Pathol., v.3, p.31-36, 2010.

RUBIN, M.A.; DUNN, R.; STRAWDERMAN, M. et al. Tissue microarray sampling strategy for prostate cancer biomarker analysis. Am. J. Surg. Pathol., v.26, p.312-319, 2002. 
SANCHEZ, I.; DYNLACHT, B.D. New insights into cyclins, CDKs, and cell cycle control. In: SEMINARS IN CELL \& DEVELOPMENTAL BIOLOGY, 2005. Proceedings... [s.1.]: Academic Press, 2005. p.311-321. (Abstract).

STANGELBERGER, A.; SCHALLY, A.V.; RICK, F.G. et al. Inhibitory effects of antagonists of growth hormone releasing hormone on experimental prostate cancers are associated with upregulation of wild-type p53 and decrease in p21and mutant p53 proteins. Prostate, v.72, p.555-565, 2012.

TOLEDO, D.C.; FALEIRO, M.B.R.; RODRIGUES, M.M.P. et al. Histomorphological characterization of proliferative inflammatory atrophy in canine prostate. Ciênc. Rural, v.40, p.1372-1377, 2010.

TSUJIMOTO, Y.; TAKAYAMA, H.; NONOMURA, N. et al. Postatrophic hyperplasia of the prostate in Japan: histologic and immunohistochemical features and p53 gene mutation analysis. Prostate, v.52, p.279-287, 2002.
WANG, H.; XU, Y.; FANG, Z. et al. Doxycycline regulated induction of AKT in murine prostate drives proliferation independently of p27 cyclin dependent kinase inhibitor downregulation. PLoS One, v.7, p.e41330, 2012.

WANG, W.; BERGH, A.; DAMBER, J.E. Morphological transition of proliferative inflammatory atrophy to high grade intraepithelial neoplasia and cancer in human prostate. Prostate, v.69, p.1378-1386, 2009.

WANG, Z.; LEE, H.J.; CHAI, Y. et al. Persistent p21Cip1 induction mediates G1 cell cycle arrest by methylseleninic acid in DU145 prostate cancer cells. Curr. Cancer Drug Targets, v.10, p.307-318, 2010.

YONG, F.; YIHONG, W.; YULEI, W. et al. A new tumour suppression mechanism by $\mathrm{p} 27^{\mathrm{Kip} 1}$ : EGFR down-regulation mediated by JNK/c-Jun pathway inhibition. Biochem. J., v.463, p.383392, 2014. 